\author{
Us, M.V. ${ }^{1}$, and Titko, I.A. ${ }^{2}$ \\ ${ }^{1}$ Yaroslav Mudryi National Law University, \\ 77, Pushkinska St., Kharkiv, 61024, Ukraine, \\ +380 57704 9293, kancel@nulau.edu.ua \\ 2 Poltava Law Institute of Yaroslav Mudryi National Law University, \\ 5, Pershotravnevyi Ave., Poltava, 36011, Ukraine, \\ +380 53256 0148, poltava_inst@nulau.edu.ua
}

\title{
PROTECTION OF ECONOMIC COMPETITION AND INTELLECTUAL PROPERTY: SEARCH FOR AN OPTIMAL REGULATORY MODEL
}

\begin{abstract}
Introduction. Failure to comply with the rules of competition is often associated with breach of intellectual property rights of other parties or misuse of these rights by authorized entities themselves.

Problem Statement. The foregoing implies a whole set of problems related to ensuring the protection of economic competition and intellectual property rights, as well as to preventing the abuse of these rights, which often leads to restrictions of competition.

Purpose. To study regulations and legislative acts concerning the protection of economic competition and intellectual property both at the national and international levels, the interaction and coherence of competition law and regulations in the field of rights to intellectual labor results.

Materials and Methods. The research is based on the legislation of Ukraine and international legal acts, as well as the practice of the national courts of Ukraine, the Court of Justice of the European Union, and the administrative practice of the European Commission. The methodological framework of the research comprises the methods for historical, dialectical, systematic, and logical research, the formal legal method, and the method of comparative jurisprudence.

Results. The relationship between the competition law and the intellectual property law has been established, the consequences of the imbalance between them (creation of monopolies, fragmentation of the internal market, market stagnation) have been identified, ways to avoid these negative consequences have been suggested.

Conclusions. The regulations and laws in the field of protection of economic competition and the exercise of intellectual property rights should be based on a model according to which the competitive behavior implies the observance of intellectual property rights of other parties, with the behavior of right owners leading to neither any restriction of competition nor any breach of consumer rights.
\end{abstract}

Keywords: intellectual property, innovations, unfair competition, antitrust regulation, restriction of economic competition, and results of intellectual labor.

Ensuring an effective competitive environment is of great importance for the implementation of economic reforms, the creation of real guarantees for the protection of the rights and interests of businessmen, their investors, and consumers. This is mainly achieved through legal regulation of relations in the field of competition.

(C) US, M.V., and TITKO, I.A., 2019
In the present-day conditions, breach of intellectual property rights of other holders, including cross-border breaches, has become the most frequent type of unfair competition.

In addition, one of the important problems the advanced economies have been facing is to find an optimal balance between the freedom of businessmen to dispose of their exclusive rights, on 
the one hand, and restrictive practices caused by the need to ensure the effective functioning of the market, on the other hand. For the countries whose economic growth rates are largely dependent on the development of technologies and innovations, ensuring the legal protection of intellectual property is of paramount importance. Too severe restrictions imposed on businessmen may be tantamount to depriving them of the ability to effectively manage their rights. This may result in the reluctance of corporations to invest in research \& innovation and assurance of product quality, poor commercialization of research and, ultimately, in market stagnation. In this regard, only finding the optimal balance between the requirements for ensuring effective competition and protecting intellectual property enables to create the most favorable environment and legal conditions necessary for successful economic development of both national and international markets.

All abovementioned considerations naturally create the need to study the legal regulation of the protection of economic competition and intellectual property both at the national (by Ukraine's example) and the international levels, as well as the interaction and harmonization of competition law and legislation in the field of intellectual property rights.

In the scholarly research literature of the postSoviet space, this problem has been considered only partially in the researches of such scholars as A. V. Bezukh, I. I. Dakhno, V. I. Eremenko, M. V. Shugurov, K. V. Entin, etc. In foreign literature, the issues of collision of the competition law and the intellectual property rights are discussed both in the publications on competition law and in researches on intellectual property law. Among the foreign researches that deal with this problem, the most notable are as follows: Protection of Competition and Intellectual Property: Demand for a New Regulatory Model That Meets the Dynamics of Economic Development by J. Lianos [1]; Resolving the Patent-Antitrust Paradox Through Tripartite Innovation by Carrier M. [2]; Fixing
Innovation Policy: a Structural Perspective by Benjamin S.M. and Rai A.K. [3].

In the course of the study, the legal and regulatory framework was the legislation of Ukraine and international legal acts, as well as the practice of the national courts of Ukraine, the EU Court and the administrative practice of the European Commission; the methodological framework consisted of the methods of historical, dialectical, systemic, and logical research. The legal specificity of the subject has led to application of the formal law method and the method of comparative law.

In Ukraine, the competition and control over unlawful restrictions of competition are provided by a separate system of regulations. It is based on the competition law that is represented by the two institutions:

1) the unfair competition prevention legislation - the Law of Ukraine on the Protection against Unfair Competition of June 7, 1996;

2) the antitrust legislation - the basic law is the Law of Ukraine on the Protection of Economic Competition of January 11, 2001.

The objectives of these legislative institutions are multidirectional: the former protects corporations from unfair actions in the market (for example, unauthorized use of trademark), while the latter prevents unlawful restrictions of competition (in particular, introduction of anti-competitive paragraphs (those that restrict access to the market for other corporations) into contracts).

Failure to comply with the rules of competition often implies a breach of other's intellectual property rights or an abuse of such rights (unlawful use of rights) by the right owners themselves.

Thus, the protection of economic competition and the exercise of intellectual property rights are subject to analysis, both in the context of unfair competition and in terms of anti-competitive restrictions in the market.

1. Unfair competition and intellectual property. The relationship between intellectual property and unfair competition is most clearly defined in 
two international universal treaties to which Ukraine is a party: the Paris Convention for the Protection of Industrial Property (1883) and the Convention establishing the World Intellectual Property Organization (WIPO) (1967). The provisions of these international acts have influenced the formation of national legislations in the field of competition and continue to have effect on the development of the international competition law and is its integral part.

First of all, it should be noted that paragraph 2 of Art. 1 of the Paris Convention contains a rather controversial provision that the protection of industrial property has as its object patents, utility models, industrial designs, trademarks, service marks, trade names, indications of source or appellations of origin, and the repression of unfair competition.

Based on paragraph VIII of Art. 2 of the Convention Establishing WIPO, "intellectual property" shall include, among others, protection against unfair competition, and all other rights resulting from intellectual activity in the industrial, scientific, literary or artistic fields. However, despite these provisions, it can be stated that the dominant doctrinal approach is that the right to protection against unfair competition cannot be referred to the intellectual property rights. It is not part of the "legal monopolies" to which the exclusive rights belong. Therefore, the conclusion that the institute of unfair competition should be included among the objects of intellectual property protection at the level of national legislations, which will enable to achieve compliance with the international documents is disputable [4, 122].

In Ukraine, the intellectual property relations are regulated by the Fourth Book of the Civil Code of Ukraine (hereinafter referred to as the Civil Code), which defines the objects and subjects of intellectual property, the basic principles and approaches to the protection of relevant rights; establishes the content of personal nonproperty and property rights and the general rules for transferring property rights to other persons, the fundamentals of protection of breached rights, etc. The $75^{\text {th }}$ and $76^{\text {th }}$ Chapters of the Fifth Book of the Civil Code deal with the regulation of contractual relations concerning the exercise of property rights on intellectual labor results. The specific details of relations in the field of intellectual property are governed by special laws, in particular, on the Protection of Rights to Trademarks and Service Marks of December 15, 1993, on the Protection of Rights to Indication of the Origin of Goods of June 16, 1999, on the Copyright and Related Rights as amended on July 11, 2001, on the Protection of Industrial Design Rights of December 15, 1993, etc.

With regard to the competition law, its provisions aim exclusively protecting the intellectual property rights in order to ensure fair competition in the market. Thus, the Law of Ukraine on Protection against Unfair Competition defines the unauthorized use of intellectual products as unfair competition in the form of unlawful use of the business reputation of a corporate entity. Art. 4 of this Law prohibits any entity from using a commercial (firm) name, a trademark (goods and service mark), packaging design of goods, and other signs without authorization from the entity who previously began to use the mentioned distinctive characteristics (or those similar to them) in its business activities, which have led or may have led to confusion between activities and products of the entities. The law defines the unlawful actions of economic entities in relation to a commercial secret as unlawful collection, use, disclosure, and inducement of disclosure (Articles 16-19).

As can be seen, these anti-competitive actions can simultaneously constitute a breach of intellectual property rights. In other words, in terms of corpus delicti (the facts and circumstances constituting a crime), unfair competition is a breach of the civil law acts.

It can be concluded that the competition law protects intellectual products. However, as A.V. Bezukh correctly points out, unlike the civilian law, it protects such products from unauthorized use 
based on imperatives rules established by the state instead of granting exclusive rights (in particular, the exclusive right to prevent any unauthorized use) [5, 147]. These rules prohibit unfair competitive actions on the market, i.e. any actions that are contrary to the commercial and other fair practice of economic activities (Article 1 of the Law of Ukraine on the Protection against Unfair Competition).

The application of unfair competition rules often reinforces and complements the legal protection provided by the civil law. For example, judicial protection of title to a trademark may be based both on the civil and the competition laws. In many countries (France, Belgium, the Netherlands, etc.), like in Ukraine, it is allowed to file the so-called joint counterfeit (breach of exclusive rights) and unfair competition claim in order to stress out that the defendant not only has faked the brand, but also used unfair means in the competition.

In the case of filing an unfair competition claim, it is crucial to prove the fact of confusion (or the possibility of confusion) between goods or services when the competitors are operating in the same business sector. In the case of confusion, the unfair competitor uses, without authorization, the business reputation that the affected corporation has gained in the market, misleading the consumer. As one can see, the competition legislation aims, among other things, at protecting potential counterparts of unfair competitor, i.e. the consumers, whereas the civil law acts protect, above all, the exclusive rights of business entities.

However, the parties are not competitors, and consequently, there is no unfair competition, if the defendant, for example, uses the claimant's name for another type of goods (services) or in connection with a different business activity. The exception is well-known trademarks and service marks. They are protected even if the offender uses them for other goods/services than they are used (Article 25 of the Law of Ukraine on the Protection of Rights to Trademarks and Service
Marks). For example, if a corporation producing biscuits with $S A M S U N G$ name indicated on the package, this is a breach of the law, insofar as the purpose of using a world-famous brand is to get an edge over competitors at the expanse of someone else's authority in the market, i.e. good reputation of a third party, not its own achievements.

It should be noted that unlawful competitive actions in the field of intellectual property do not concern all objects the rights to which are protected by the civil law, but only those which use can lead to unfair competition. Among such objects in the Law on the Protection against Unfair Competition, there are explicitly mentioned the commercial (firm) name, trademarks (service marks), and commercial secrets. Certainly, proceeding from the provisions of this Law, industrial designs, utility models, inventions, names of literary and artistic works, periodicals, indication of the origin of goods, etc. can be referred to the objects of intellectual property, which can be used in unfair competition. At the same time, it roughly outlines unfair competitive actions in the field of intellectual property. This approach of the legislator is consistent with the letter and spirit of Art. 10-bis [Unfair Competition] of the Paris Convention for the Protection of Industrial Property of March 20, 1883.

At the same time, the Law of Ukraine on the Protection against Unfair Competition protects the results of intellectual labor that is not subject to legal protection under the civil law. The matter is that not all of them can be referred to the objects of intellectual property, since the key feature of the latter is their recognition as such at the legislative level. As V.A. Dozortsev put it, if the law (generally, not only a codified act) contains a provision to protect an object, it is protected; if there is no such a provision, it is not protected; neither absolute nor quasi-absolute protection can be established by agreement of the parties; the same concerns the law - it must exhaustively define the content of each type of exclusive rights, the procedure for their application and exercise $[6,10]$. 
For example, Art. 6 of the aforementioned Law prohibits copying the appearance of any product of other corporation and its introduction into economic activity unless the manufacturer of the copy is explicitly indicated, which may lead to confusion between the corporations. In this case, it is referred to industrial design, since, pursuant to Art. 461 of the Civil Code, the object of industrial design may be shape, pattern or color, or their combination, by which the product appearance is identified. In accordance with Art. 465 of the Civil Code, intellectual property rights to industrial design (including the exclusive right to prevent its unauthorized use and to prohibit such use) shall come into effect from the date following the date of their state registration and expire in 15 years after the date of filing the application for industrial design in the manner prescribed by the applicable law. Art. 6 of the Law prohibits any unauthorized use of appearance of products for which no protection documents have been obtained or the period of validity of exclusive property rights for has already expired, provided they have gained a good reputation in the market. For example, in practice, there are many replicas of clothes and shoes of famous manufacturers and designers. Usually, they do not protect such models with a patent for an industrial design. In this case, such protection is governed by Art. 6 of the Law on the Protection against Unfair Competition.

Special attention should be paid to the fact that in accordance with Part 1 of Art. 424 of the Civil Code, the legislator identifies both the right to use the object of intellectual property and the exclusive right to prevent its unauthorized use, including to prohibit any such use. This implies that in the case of entering into a license agreement that authorizes to use the object (Part 1 of Article 1109 of the Civil Code), in general, the right holder transfers only the right to use, while retaining the right to prevent any unauthorized use by third parties. In addition, Part 5 of Art. 16 of the Law of Ukraine on the Protection of Rights to Trademarks and Service Marks states that on- ly a certificate of trademark registration gives its holder the exclusive right to prevent any unauthorized use of the trademark. Also, pursuant to par. 3 of Part 2 of Art. 20 of this Law, the licensee has the right to demand reversion of the licensor's breached rights only with the licensor's consent.

Let us imagine a situation that a licensee who uses intellectual property of other corporation under licensing agreement has gained a good reputation in the market on its own, and third parties commit deeds having signs of unfair competition, but the licensor, for various reasons, does not react to such breaches. In this situation, the licensee can be protected by the Law on the Protection against Unfair Competition, if the license agreement does not contain a provision that the licensee is granted with the right to prohibit any unauthorized use of the object.

Considering the above, it can be concluded that the competition law, as compared with the civil law, provides a broader range of protection means to certain intellectual products, since it protects them from the moment of use, while the civil law often gives priority to the registration with which the origin of exclusive rights to respective intellectual property is associated.

Certainly, the protection in the sphere of competition is more effective if the intellectual product is protected by a copyright in accordance with the requirements of the civil law. In this case, as already mentioned, to protect the rights, one can refer both to the norms of the competition and the civil law. In addition, if there is no registration certificate, the applicant must confirm the presence of business reputation for the mark [5, 169], which, of course, is more difficult than to present a copyright protection.

It should be noted that the interaction of the competition and the civil law in the field of intellectual property is directly established at the legislative level, in some national legislative systems. Thus, in accordance with paragraph 7 of Art. 1252 of the Civil Code of the Russian Federation, if a breach of the exclusive right to a result 
of intellectual labor or to a means of individualization has been recognized as unfair competition, in the established order, the breached exclusive right can be protected both by the tools provided by this Code and in accordance with the antitrust law.

Ukraine's legislation does not establish this relationship in the Civil Code. Part 5 of Art. 13 of the Civil Code deals with limits of exercise of the civil rights and specifies only that no unfair competition shall be admitted. At the same time, Part 3 ibid. forbids any actions aiming at causing loss and damage to other parties, as well as any abuse of rights in whatever form.

This draws attention to the fact that unfair competition can be realized not only as a breach of someone's intellectual property rights (for example, unauthorized copying of someone's industrial design), which is the most common form, but also, in some situations, as acquisition and use of exclusive right without breaching any intellectual property rights of other parties. Thus, in the latter case, one of the acts of unfair competition is registering a trademark similar to a widely known unregistered name, followed by its usual use (i.e., without a purpose to receive a redeem for the mark by prohibiting its holder from the use of the mark), thereby parasitizing on reputation of the widely known unregistered name. At the same time, the mentioned form of unfair competition should be distinguished from the breach of exclusive right to a well-known trademark, the legal protection of which is not limited in time and applies to goods that are not congeneric with those for which it is considered well-known (the above example of the SAMSUNG trademark).

In turn, the willful registration and subsequent use of the exclusive right to a trademark in the form of prohibiting third parties from its use in the states with an effective law enforcement is recognized as a monopolistic deed, not unfair competition. This is a classic form of abuse of the right in the field of intellectual property, i.e. abuse of a monopoly based on exclusive rights (based on the national legislation, this is prohibited by
Article 13 of the Law of Ukraine on the Protection of Economic Competition). Indeed, the offender's goal in this case is to oust competitors from a certain segment of the market, to restrict competition until it is completely eliminated, which is not inherent in unfair competition that is characterized by distortion (perversion) of competition, but never reaches its complete abolishment [7, 23].

It should be noted that at the international level, in the context of counteracting unfair competition in the field of intellectual property, the main international organization dealing with improving the national policy and legislation in the field of competition, as well as with developing international cooperation in this field, is UNCTAD (the UN Conference on Trade and Development that is the body of the UN General Assembly). It coordinates its activities with the UN Commission on International Trade Law UNCITRAL, the World Trade Organization (WTO), and the Organization for Economic Cooperation and Development (OECD). However, the protection of intellectual property in the process of facilitating the world trade development is not among the UNCTAD priorities.

The most important direction of reducing the number of cases of unfair competition related to unauthorized use of intellectual property is the further development of intellectual property rights and the enhancement of protection and enforcement of intellectual property rights. In this area, the key international organization is the World Intellectual Property Organization (WIPO) as a specialized UN agency. However, since the WIPO activities are not focused on the protection of intellectual property rights in the course of their commercialization, this gap is filled by the WTO. It seems that the purpose of the WTO Agreement on Trade-Related Aspects of Intellectual Property Rights of 1994 (TRIPS) in this aspect is to combine trade development, competition, and intellectual property protection $[4,125]$.

Despite the fact that the WTO is focused on the protection of intellectual property in the 
course of its commercialization, the organization is not directly involved in the development of measures for counteracting unfair competition based on the unauthorized use of intellectual property. However, this does not mean that the WTO is not interested in competition issues in general. On the contrary, being an economic organization, it proceeds from the postulate that the competition and the competition policy are tools for facilitating economic growth.

Proceeding from the above, it can be stated that one of the problems of international cooperation in the analyzed area is institutional "blur". Therefore, the UN agencies having their specializations, the further development of regulations and effective measures to curb unfair competition associated with the unauthorized use of intellectual property objects requires a more integrated cooperation of UNCTAD, WTO, WIPO and other international organizations [4, 125].

2. The competition law and intellectual property. The competition law and the intellectual property law have a common goal that is to promote innovations and to facilitate market transformations for the good of the current and future consumers. Therefore, it is very important to ensure the relationship between these two branches of legislation in such a way that both of them aim at achieving this common goal. Any shift towards the intellectual property rights can entail the creation of monopolies and the fragmentation of the domestic market, while that towards the competition law can deprive corporations of the ability to effectively manage their rights, which adversely affects their incentive to invest in research or promotion their products and, as a result, leads to market stagnation $[7,6]$.

The interaction of the antitrust legislation with legal acts in the field of intellectual property has a long history. At the end of the $19^{\text {th }}$ century, when the first antitrust laws were passed in Canada and the USA, there arose contradictions between them and the patent legislation, since it became possible to consider the limitations of license agreements as a breach of antitrust laws.
Sometime, this conflict seemed to run its course, but at some point it took the next turn, which was reflected in contradictory court decisions [8, 32].

In the European Union, at the level of the European Court of Justice, the issue of recognizing the use of intellectual property rights by corporations as an abuse of their dominant position for the first time arose in the cases of Volvo (1987) and Renault (1987), when the EU Court established that the holder of rights to industrial design should not be obliged to issue to third parties, even for a reasonable fee, a license to manufacture of goods incorporating this design insofar as such obligation would be equivalent to depriving the holder of the nature of his exclusive right. Consequently, the refusal to issue a license does not constitute an abuse of dominant position. Thus, the EU Court has adopted an approach according to which the provisions on the right of competition should not deprive the right holder of the nature of his rights $[9,99]$.

The example from judicial practice has clearly demonstrated that initially, the standards for applying the antitrust regulation to the intellectual property law in Europe (like in the United States) were very mechanistic with a focus on the scope of intellectual property rights, their value and functions [2]. In other words, in each case concerning the application of antitrust regulation to the use of intellectual property rights, these standards were based on a mechanical analysis of the scope of exclusive rights, their value, market function or intent of the patent holder, not on an estimate of specific economic effects that the use of intellectual property rights had on innovative development or on spread of knowledge and technology. Recently, the antitrust authorities of advanced economies (the EU member states, USA, Japan, South Korea), as well as some emerging markets (for example, China) have adopted a more balanced approach that enables to measure directly or by means of estimation the impact of the use of intellectual property rights on public welfare. This use can be considered anti-competitive, proceeding not only from the current state 
of the market, but also from an estimate of the dynamics of market changes, if it is possible in each specific case. This approach is more focused on economic analysis as compared with mechanistic estimation of the use of intellectual property rights and, at the same time, is more difficult to apply. In most cases, it can lead to the competition rights prevailing over the intellectual property rights [1].

In the applicable legislation of Ukraine, the problem of relationship between the antitrust law and the intellectual property has been addressed as follows. The intellectual property rights are exclusive: the holder has a sole right to prohibit, to authorize, and to receive proceeds of the use of his intellectual products. At the same time, the state authorities that issue patents and certificates for individual objects inexplicitly confirm such a monopoly right of the author (inventor). Therefore, from the point of view of the civil law, the monopoly of exclusive right holder is lawful.

However, absolute monopoly is inadmissible. A kind of "conflict of interest" between the competition law and the intellectual property rights arises when the use of rights to the results of intellectual labor by right holding corporations bears a risk of breaking an effective competition in the domestic market. This occurs in situations where: firstly, the intellectual property rights are subject to consortiums that can disrupt competition in the domestic market; secondly, the exercise of intellectual property rights by a dominating corporation is an abuse and prohibited by the applicable competition law [9, 4].

So, Art. 6 of the Law of Ukraine on the Protection of Economic Competition prohibits any anticompetitive concerted actions putting any restrictions or limitations on the commodity markets or on the access to the market for other corporations, customers, etc. In addition, Art. 9 of the same Law establishes that these rules do not apply to agreements on the transfer of intellectual property rights or on the use of an object of intellectual property rights to the extent that they restrict the counterparty from doing its business, provided these restrictions do not go beyond the lawful rights of the subject of the intellectual property law. Such legitimate restrictions include restrictions on the scope of rights transferred, term and territory of validity of authorization to use the object of intellectual property rights, as well as on the type of activity, scope of use, and minimum output. This legislative clarification is important because it determines which particular conditions of license agreements in the field of intellectual property do not contradict the competition.

In the context of abuse of dominant position Art. 13 of the Law prohibits to condition making agreements with imposing on the licensee any additional obligations that, by their nature or in accordance with commercial or other fair practice, do not concern the subject matter of the agreement; to create any barriers for entering/quitting the market; or to oust sellers, buyers, other corporations, etc. from the market.

As can be seen, the norms of the competition law partially restrict the ability of intellectual property right holder to exercise, at his own discretion, the rights established by the civil law. However, such restrictions are fully consistent with the provisions of the latter. So, Part 5 of Art. 13 of the Civil Code states that it is not allowed to use civil rights for restricting competition in an unlawful manner and abusing a monopoly position in the market. In addition, Art. 424 of the Civil Code states that exceptions and restrictions in respect of intellectual property rights may be established by law. However, the same article says that such limitations and exceptions should not create significant obstacles to exercising intellectual property rights and legitimate interests of the subjects of these rights. As I.I. Dakhno correctly noted, the legislator's task is to find the golden mean: the patent monopoly should stimulate the technical progress without suppressing the competition [10,121].

In the modern judicial practice of the European Union, a common example of anticompetitive concerted action in the EU market can be 
trademark delimitation agreements. Thus, the European Commission that acts as an antitrust authority at the EU level, has refused to approve an agreement between the manufacturers of two medical products Sintex and Sintelabo, according to which the latter lost the right to use its Synthelabo and Synthelab trademarks in the United Kingdom, in order to prevent any confusion between the above mentioned trademarks and Syntex, Syntrex, Syndrex, Synodex, and Synlexan trademarks owned by Syntex. When making its decision, the EU Commission was guided by considerations that the risk of confusion between trademarks cannot be a reason for dividing the common market $[9,72]$.

A decisive contribution to determining the balance between the intellectual property protection and the requirements of competition law was made by well-known decision of the EU Commission on the Microsoft case of March 24, 2004. In 2000, the European Commission launched an investigation into the activities of Microsoft following a complaint from Sun Microsystems, one of Microsoft's main competitors in the server market. In the course of this investigation, the European Commission concluded that Microsoft breached Art. 102 of the Treaty on the functioning of the EU (prohibition against abuse of dominant position) since it refused to provide its competitors (including Sun Microsystems) with the information necessary to ensure that software developed by them was fully interoperable with Microsoft products. Initially, the American giant provided other companies with access to its infrastructure, but over time, decided to deny it. This relegated to a secondary position competition in terms of reliability, security and speed, among other factors, and ensured Microsoft's success on the market. As a result, an overwhelming majority of customers informed the Commission that Microsoft's non-disclosure of interface information artificially altered their choice in favor of Microsoft's server products.

According to the Commission, by restricting access to information protected with intellectual property rights Microsoft acquired a dominant position in the market for work group server operating systems that are at the heart of corporate IT networks. The information required by the applicants was recognized as significant for the competition, since it was necessary to maintain the market of working servers viable [9, 118, 124].

The decision on the Microsoft case aroused a great interest not only among the lawyers, but also among the general public. Firstly, it concerned one of the largest global corporations (at that time, Microsoft was the third world largest company in terms of capitalization). Secondly, the Commission imposed an unprecedented fine for abuse of dominant position of EUR 497169 $304[9,116]$.

In modern conditions, it is possible to propose several ways to harmonize the competition law with the intellectual property legislation, both at the national and the international levels, which would reduce the existing "tension" between the competition regulation and the use of rights to the results of intellectual labor.

Firstly, to enhance mutual enrichment in terms of improving norms of the substantive law. The competition law may use values of intellectual property, for instance, creating incentives for innovation. In its turn, the intellectual property law can incorporate the values of the competition law, shifting its focus towards access to knowledge and dissemination of information [1, 54].

Secondly, to integrate economic analysis in the creation of optimal legal regimes and regulations in the field of intellectual property. Focusing on economic effects of intellectual property and competition policy on welfare and innovation can reduce the tension between these branches of law [1, 57].

Thirdly, there are reasonable proposals on the need to assign different functions to one body or to create a comprehensive innovation development department responsible for coordinating innovation policy pursued by different government services and regulatory agencies, for example, the Agency for Innovation Policy [3, 1]. 
Based on the foregoing, it can be concluded that the provisions of legislation in the field of intellectual property are partially adjusted by the rules of competition laws. On the one hand, the latter provides a broader protection of intellectual products and, on the other hand, restricts intellectual property rights in order to ensure an effective competitive environment in the market.

The general trend in the development of legis- lative framework for preventing anti-competitive actions with the use of intellectual property objects should be forming standards for a balance between protection of intellectual property and free fair competition. This balance means that competitive behavior must imply respect for intellectual property rights. In turn, exclusive right holders must not breach the rules of competition in the market.

\title{
REFERENCES
}

1. Lianos, J. (2016). Protecting competition and intellectual property: the demand for a new regulatory model that corresponds to the dynamics of economic development. Law, 2, 46-62 [in Russian].

2. Carrier, M. (2003). Resolving the Patent-Antitrust Paradox Through Tripartite Innovation. Vanderbilt Law Review, 56, 1047-1111.

3. Benjamin, S. M., Rai, A. K. (2008). Fixing Innovation Policy: A Structural Perspective. The George Washington Law Reviеге, 77, 1-88.

4. Shugurov, M. V. (2014). International legal grounds for protection against unfair competition in the field of intellectual property. The modern law, 8, 121-128 [in Russian].

5. Bezukh, O. V. (2001). Value of legislation on protection against unfair competition with the legislation regulating the use of other objects of intellectual property. Bulletin of economic proceedings, 1, 168-175 [in Ukrainian].

6. Dozortsev, V. A. (2000). The notion of the exclusive right. The legal world, 3, 4-11 [in Russian].

7. Eremenko, V. I. (2014). The ratio of intellectual property and unfair competition. Competitive lare, 3, 13-25 [in Russian].

8. Eremenko, V. I. (2002). Theoretical aspects of Russian competition law. State and Lare, 2, 29-30 [in Russian].

9. Entin, K. V. (2011). The right of competition and protection of intellectual property in the practice of the EU Court and the European Commission. (Doctoral dissertation). MGIMO University, Moscow [in Russian].

10. Dakhno, I. I. (1998) Antimonopoly law: course of lectures. Kyiv: Fourth wave [in Ukrainian].

Received 03.10.18

\author{
M.B. Y $^{1}$, I.A. Тітко ${ }^{2}$ \\ ${ }^{1}$ Національний юридичний університет імені Ярослава Мудрого, \\ вул. Пушкінська, 77, Харків, 61024, Україна, \\ +380577049293, kancel@nulau.edu.ua \\ ${ }^{2}$ Полтавський юридичний інститут \\ Національного юридичного університету імені Ярослава Мудрого, \\ проспект Першотравневий, 5, Полтава, 36011, Україна, \\ +380 53256 0148, poltava_inst@nulau.edu.ua

\section{ПОШУК ОПТИМАЛЬНОЇ МОДЕЛІ РЕГУЛЮВАННЯ} \\ ЗАХИСТ ЕКОНОМІЧНОЇ КОНКУРЕНЦІЇ ТА ІНТЕЛЕКТУАЛЬНА ВЛАСНІСТЬ:
}

Вступ. Недотримання правил конкурентної боротьби часто є порушенням чужих прав інтелектуальної власності або їх неправомірне використання самими уповноваженими суб’єктами.

Проблематика. Вище викладене спричиняє блок проблем, пов'язаних із забезпеченням захисту економічної конкуренції та одночасною охороною прав інтелектуальної власності, а також недопущенням зловживання останніми, що часто призводить до обмеження конкуренції.

Мета. Вивчення законодавчого регулювання захисту економічної конкуренції та інтелектуальної власності як на національному, так і на міжнародному рівнях, а також дослідження взаємодії та узгодженості конкурентного законодавства і законодавства у сфері прав на результати інтелектуальної діяльності.

Матеріали та методи. Інформаційну основу дослідження склали законодавство України та міжнародно-правові акти, а також практика національних судів України, Суду ЄС та адміністративна практика Європейської Комісії. 
Методологічною основою слугували методи історичного, діалектичного, системного та логічного дослідження, формально-юридичний метод, метод порівняльного правознавства.

Результати. Встановлено взаємозв'язок між конкурентним правом і правом інтелектуальної власності, з'ясовано наслідки порушення балансу між ними (створення монополій, дроблення внутрішнього ринку, стагнація ринку), запропоновано шляхи уникнення зазначених негативних наслідків.

Висновки. В основі законодавчого регулювання захисту економічної конкуренції та здійснення прав інтелектуальної власності повинна лежати модель, відповідно до якої конкурентна поведінка передбачає дотримання чужих прав інтелектуальної власності, в свою чергу, поведінка власників таких прав не призводить до обмеження конкуренції та порушення прав споживачів.

Ключові слова: інтелектуальна власність, інновації, недобросовісна конкуренція, антимонопольне регулювання, обмеження економічної конкуренції, результати інтелектуальної діяльності.

\author{
М.В. $У_{C}{ }^{1}$, И.А. Титко ${ }^{2}$ \\ ${ }^{1}$ Национальный юридический университет имени Ярослава Мудрого, \\ ул. Пушкинская, 77, Харьков, 61024, Украина, \\ +380 577049293 , kancel@nulau.edu.ua \\ ${ }^{2}$ Полтавский юридический институт Национального юридического \\ университета имени Ярослава Мудрого, \\ проспект Первомайский, 5, Полтава, 36011, Украина, \\ +380532560148, poltava_inst@nulau.edu.ua

\section{ЗАЩИТА ЭКОНОМИЧЕСКОЙ КОНКУРЕНЦИИ \\ И ИНТЕЛЛЕКТУАЛЬНАЯ СОБСТВЕННОСТЬ:} \\ ПОИСК ОПТИМАЛЬНОЙ МОДЕЛИ РЕГУЛИРОВАНИЯ
}

Введение. Несоблюдение правил конкурентной борьбы часто представляет собой нарушение чужих прав интеллектуальной собственности или их неправомерное использование самими управомоченными субъектами.

Проблематика. Вышеизложенное порождает блок проблем, связанных с обеспечением защиты экономической конкуренции и одновременной охраной прав интеллектуальной собственности, а также недопущением злоупотребления последними, которое часто приводит к ограничению конкуренции.

Цель. Изучение законодательного регулирования защиты экономической конкуренции и интеллектуальной собственности как на национальном, так и на международном уровнях, взаимодействия и согласованности конкурентного законодательства и законодательства в сфере прав на результаты интеллектуальной деятельности.

Материалы и методы. Информационную основу исследования составили законодательство Украины и международно-правовые акты, а также практика национальных судов Украины, Суда ЕС и административная практика Европейской Комиссии. Методологической основой служили методы исторического, диалектического, системного и логического исследования, формально-юридический метод, метод сравнительного правоведения.

Результаты. Установлена взаимосвязь между конкурентным правом и правом интеллектуальной собственности, выявлены последствия нарушения баланса между ними (создание монополий, дробление внутреннего рынка, стагнация рынка), предложены пути избежания указанных негативних последствий.

Выводы. В основе законодательного регулирования защиты экономической конкуренции и осуществления прав интеллектуальной собственности должна лежать модель, в соответствии с которой конкурентное поведение предполагает соблюдение чужих прав интеллектуальной собственности, в свою очередь, поведение обладателей таких прав не приводит к ограничению конкуренции и нарушению прав потребителей.

Ключевые слова: интеллектуальная собственность, инновации, недобросовестная конкуренция, антимонопольное регулирование, ограничение экономической конкуренции, результаты интеллектуальной деятельности. 